\title{
Who will make medical decisions for you if you can't make them yourself?
}

Murray Sagsveen, JD; and Michael A. Williams, MD

\begin{abstract}
Your right to decide
You have the right to make decisions about your medical care. But what if you become too ill to make the decisions? Does your family know your wishes? Does your doctor? It is important to talk about your wishes, and it is just as important to explain your wishes in a written "advance directive." A written directive can help your loved ones make medical decisions for you if you can't make them for yourself.
\end{abstract}

\section{What is a health care advance directive?}

A written statement concerning future medical treatment is a health care advance directive, which may include a 1) living will and 2) a health care power of attorney. A living will explains your wishes and your goals of care. A health care power of attorney appoints another person (sometimes called an "agent") to make your health care decisions if you are unable to do so.

\section{Why must a health care advance directive be in writing?}

Sometimes illness, especially neurologic disorders affecting the brain, such as stroke, Alzheimer disease, and traumatic brain injury, can cause a person to lose the ability to express his or her choices. Thus it is important for you to discuss your wishes for medical care with your family members and family physician in advance, even if you don't anticipate such an illness affecting you. To be effective, both legally and practically, a health care advance directive should be written to comply with the laws of your state. Oral instruc- tions may be misunderstood, may not comply with state law, and may not be accepted by a court if family members disagree about your medical treatment.

\section{Selection of a health care agent}

A health care agent is a person who will have the power to make decisions regarding your medical care with your doctors, including whether to limit or stop treatment. The choice of this person is a very personal decision; you should select someone you believe understands your wishes and talk with them in advance to be sure they accept the responsibility to make health care decisions for you. Make sure your family and your doctors know who you've selected.

\section{What kinds of decisions can my health care agent make?} In your advance directive, you can identify the types of decisions you want your health care agent to make for you. In the absence of your specific instructions, a health care agent can make almost any decision that you would normally make; however, there is state-tostate variation in the authority given a health care agent. The most important decisions are often those made when you are critically or seriously ill, such as whether to attempt resuscitation if you have a cardiac arrest; or whether to continue intensive care treatments, chemotherapy, or other therapies if it appears that the chances of success are getting smaller; or whether to use a feeding tube to administer fluids and nutrition.

\section{What if I don't have an advance directive or designate a health care agent?}

If you don't make these choices, then the laws in your state will determine who is entitled to make choices on your behalf, and the laws may also limit the types of decisions the health care agent can make for you. By creating an advance directive and designating a health care agent, you select who makes those important decisions. In addition, you will reduce the chances that there would be an argument over the decisions to make, and who would make those decisions for you.

\section{Where may a person obtain approved forms?}

Federal law requires most hospitals, nursing homes, and home health agencies to routinely provide information about advance directives during the admission process. You may also obtain information and approved forms from state and local public health departments, your lawyer, and national organizations that provide information and forms on their Web sites.

\section{Where should you keep your health care advance directive?}

You should keep the original health care advance directive in a safe place where your family and health care agent can easily find it. You should also provide copies to your doctor (to be placed in your medical record), your agent (and any alternate agents), your family members, your preferred health care facility, and your lawyer. 


\section{Additional information about advance directives}

The following national organizations have excellent Web sites that provide information about advance directives, including state-specific forms:

www.neurology.org

- Consumer's Tool Kit for Health Care Advance Planning ABA Commission on Law and Aging www.abanet.org/aging/toolkit/home.html

- 10 Legal Myths About Advance Medical Directives http://www.abanet.org/aging/myths.html

- AARP resources about living wills http://www.aarp.org/bulletin/yourhealth/resources_wills.html

- Health Care Advance Directives http://www.abanet.org/publiced/practical/directive_whatis.html

- Put it in Writing: Questions and Answers on Advance Directives American Hospital Association www.putitinwriting.org/putitinwriting/content/piiwbrochure.pdf

- Living wills and other tools to convey medical wishes Mayo Clinic www.mayoclinic.com/health/living-wills/HA00014

- Caring Connections (includes links to state-specific forms) National Hospice and Palliative Care Organization www.caringinfo.org/i4a/pages/Index.cfm?pageid $=3278$

- Decisions about End-of-Life Care American Medical Association Journal of the American Medical Association Patient Page http://jama.ama-assn.org/cgi/reprint/284/19/2550.pdf 


\section{Neurology}

\section{Who will make medical decisions for you if you can't make them yourself? \\ Murray Sagsveen and Michael A. Williams \\ Neurology 2006;66;E9-E10 \\ DOI 10.1212/01.wnl.0000198644.92349.a6}

\section{This information is current as of January 24, 2006}

\section{Updated Information \&} Services

Citations

Permissions \& Licensing

Reprints including high resolution figures, can be found at: http://n.neurology.org/content/66/2/E9.full

This article has been cited by 1 HighWire-hosted articles: http://n.neurology.org/content/66/2/E9.full\#\#otherarticles

Information about reproducing this article in parts (figures,tables) or in its entirety can be found online at:

http://www.neurology.org/about/about_the_journal\#permissions

Information about ordering reprints can be found online: http://n.neurology.org/subscribers/advertise

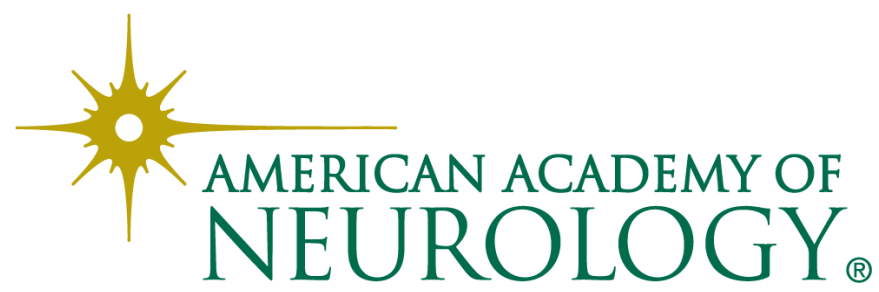

